\section{Health care workers and AIDS: a differential study of beliefs and affects associated with accidental exposure to blood}

\author{
Profissionais de saúde e AIDS: um estudo \\ diferencial sobre crenças e afetos associados \\ à experiência de exposição acidental a material \\ biológico potencialmente contaminado
}

Maria Rosa Rodrigues Rissi 1

Alcyone Artioli Machado 2

Marco Antonio de Castro Figueiredo 1

\footnotetext{
1 Faculdade de Filosofia, Ciências e Letras de Ribeirão Preto, Universidade de São Paulo,

Ribeirão Preto, Brasil.

2 Faculdade de Medicina de Ribeirão Preto,

Universidade de São Paulo, Ribeirão Preto, Brasil.

Correspondence M. R. R. Rissi

Departamento de Psicologia e Educação, Faculdade de Filosofia, Ciências e Letras de Ribeirão Preto, Universidade de São Paulo. Rua Terezina 380, apto. 24 Ribeirão Preto, SP 14055-380, Brasil. mariarosarr@yahoo.com
}

\begin{abstract}
This study aimed to analyze affective and cognitive determinants of the professional work of individuals caring for patients with HIVIAIDS, in view of the risk and/or experience of accidental exposure to blood. We drew on the theoretical-methodological references of Fishbein \& Ajzen and Maslow's theory. Fifty health care workers were evaluated using an attitudes questionnaire and a needs and motivations instrument. The research verified differences between answers by health care workers who had never suffered accidents and those who had already experienced accidental exposure to blood. Health care workers did their work activities motivated by the need for self-fulfillment and valued their own performance when they were able to meet the patients' emotional needs. Among health professionals who had never experienced accidental exposure to blood, the predominant beliefs was that patients feel remorse over having expose themselves to HIV. Accidental exposure to blood raises difficulties in personal life. Technical aspects are also associated with the possibility of accidental exposure to blood.
\end{abstract}

Health Care; Occupational Accidents; Acquired Immunodeficiency Syndrome

\section{Introduction}

During their professional experience, health care workers who care for individuals with HIV/AIDS need to be qualified to deal with the specific requirements of the syndrome, which demands technical and scientific knowledge and understanding of the ties established between the clinical team and patients with HIV/ AIDS. An implicit concern during daily practice by health care workers is the possibility of infection with pathogens through accidental exposure to blood.

Several studies $1,2,3,4,5$ have attempted to shed light on the extent of the problem from a clinical and epidemiological point of view, besides defining prophylactic post-exposure measures, but questions related to the psychological implications of accidental exposure to blood have rarely been discussed in the literature 6,7,8,9.

Some published studies and relevant informal observations have indicated that accidental exposure is experienced with great anxiety by the health care workers, and work by professionals caring for patients with HIV/AIDS thus goes beyond intrinsic technical aspects, requiring another dimension of care which includes awareness of patients' psychosocial needs, indicating concern for the more human side of the issue $4,10,11,12$.

It thus seems evident that in addition to training for AIDS care as a whole, it is crucial to 
understand the different psychosocial aspects inherent to health professionals' practical work 13,14 , indicating the increasing need for support programs and psychological help in order to establish a less threatening and more genuine relationship with the patient.

In the present study, the Fishbein-Ajzen affective-cognitive model was used, which conceives attitude as the result of the conjunction of beliefs, values, and emotions 15 associated with any phenomenon 16 , a model representing an advance in the study of social attitudes.

To investigate the direction of motivations and needs inherent to professional activity, Maslow's theory was also used 17,18 . This model proposes a hierarchy of human needs, supporting the theory that individuals act in such a way as to satisfy or reduce their needs according to factors inherent to their personality.

The theory's general principle is that individuals have primary or physiological needs which, when satisfied, make way for secondary needs, which in turn acquire the power of motivation. In this respect, these models are believed to fulfill the objective of identifying affective and cognitive determinants that lead health care workers to work with AIDS.

The objectives of the present study were: (1) to analyze affective and cognitive determinants of professional work by individuals caring for patients with HIV/AIDS, using assessment instruments, and (2) to determine which representations and motivations are part of the experience of these professionals in view of accidental exposure to blood risk and/or experience.

\section{Population and methods}

\section{Study site}

The study was carried out at the Special Unit for Treatment of Infectious Diseases (SUTID), a regional reference center for this type of care. The unit is a department of the University Hospital, School of Medicine, Ribeirão Preto, University of São Paulo (HCFMRP-USP), a 600-bed facility with various medical specialties. The city of Ribeirão Preto has a population of approximately 500,000 and is located in northeastern São Paulo State, Brazil.

The research project was approved by the Institutional Review Board/Research Ethics Committee of HCFMRP-USP (HCRP case no. 1170/99). All health care workers participating in this study received detailed written information on the study procedures and objectives, and only those who provided their consent to participate were included, after signing the document.

\section{Study phases}

\section{- Survey of prevalent modal beliefs}

(a) Subjects: Fifteen subjects participated in the first phase of the study after written informed consent was obtained, including five nurses and ten nurse technicians who care for patients treated at the SUTID.

(b) Procedures:

1. Interviews: Subjects answered individual semi-structured interviews, following a procedure of evocation-enunciation-verification, in order to obtain data regarding three categories of representation: work itself, patients with HIV/AIDS, and accidental exposure to blood.

2. Content analysis and verification of the selected beliefs: During this phase, a list of statements was presented to three reviewers who grouped those that showed the closest content-related proximity. The statements that were found to be at the judgment intersection for each category were then verified graphically using the Venn diagram 19.

3. Construction of affective-cognitive scales: Content analysis of the selected beliefs permitted their association with "b" scales, which evaluate affective contents, and "e" scales, which evaluate cognitive contents, using a 7-point Likert type scale ranging from +3 to -3 with a median interval of zero 20 .

\section{- Application of a questionnaire for evaluation of needs and motivation:}

(a) Subjects: Fifty health care workers participated in this phase of the study, including 13 physicians, 9 nurses, 22 nurse technicians, 5 general service technicians, and 1 dentist, who provide services in the SUTID. Inclusion criteria were the type of activity carried out, their link with the service, and their availability and willingness to participate in the study.

(b) Procedures: The questionnaire for evaluation of needs and motivation was administered at the subjects' workplace. The responses were then submitted to descriptive analysis according to the variable "health care workers with a history of accidental exposure to blood" and "health care workers without a history of accidental exposure to blood". On the basis of this analysis, cutoff points were established and subgroups defined for differential analysis.

After statistical analysis, distribution of responses within the levels of need satisfaction 
was determined using Maslow's theory 21. Data were analyzed for differences between satisfaction levels and for each differential group.

\section{- Determination of health professionals attitudes towards certain categories of AIDS-related contents}

(a) Subjects: The same 50 subjects evaluated during the previous step were assessed during this phase.

(b) Procedures: This phase consisted of three steps as proposed by Figueiredo 20:

1. Application of the attitude instrument: Fifty observations were made by applying two probability scales using a 7-point Likert evaluation in order to determine affective "e" and cognitive " $b$ " attitude components. The responses were processed on the basis of the FishbeinAjzen equation, calculating the relative attitudes for each item and each category studied.

2. Differential studies: Differential studies were carried out using the t-test and Mann-Whitney test for the determination of differences within each subgroup ("health care workers with a history of accidental exposure to blood" and "health care workers without a history of accidental exposure to blood"), with the level of significance set at $\mathrm{p}<0.5$ for rejection of the equality hypothesis. Descriptive statistics were also applied to the data for each sub-sample when differences were observed, or for the whole sample $(n=50)$ when differential analysis did not reveal any difference, considering all categories evaluated.

3. Quadrant analysis: To determine the conjugation of cognitions and emotions leading to the attitudes evaluated, quadrant analysis consisting of the trisection between the "b" scores on the abscissas and the "e" scores on the ordinates of the beliefs-versus-values relationship was carried out. Conjugations were determined based on the distribution of subjects among quadrants using the scores obtained by the two scales. The modal quadrant was compared to the sum of the remaining quadrants, with the level of significance set at $\mathrm{p}<0.5$ for rejection of the equality hypothesis. The results were interpreted and discussed on the basis of the meaning of the modal quadrant.

\section{Results}

\section{Survey of prevalent modal beliefs}

Table 1 shows the final list of statements selected on the basis of content analysis, which form the attitude instrument. A predominance of contents related to the characteristics of the relationship established between healthy care workers and patient can be noted, as well as contents related to work contingencies and psychosocial aspects of the patients that render work with AIDS specific as compared to other diseases.

\section{Determination of satisfaction rates using a needs instrument}

Table 2 shows the distribution of different needs satisfaction rates for health care workers with and without a history of accidental exposure to blood. For those accidentally exposed to blood, the results indicate satisfaction in terms of the need for security (54\%) and a tendency towards satisfaction with the need for self-fulfillment (40\%), but lack of satisfaction of more basic needs such as survival, a need which most professionals found to be unmet (72\%).

According to the distribution of needs satisfaction rates for health care workers who had never been accidentally exposed to blood, the needs of security and self-fulfillment were satisfied, with both needs showing a $64 \%$ satisfaction rate. A tendency towards satisfaction was also observed in the need for socialization $(36 \%)$. In contrast, a high rate of lack of satisfaction was observed in relation to survival (54\%) and self-esteem (41\%).

\section{Summary of results obtained by quadrant analysis}

Table 3 shows an analysis of the conjugation of "b" and "e" values assigned to the statements presented to the subjects as shown in Table 1 . Quadrant analysis based on the conjugation of beliefs and values for the work category demonstrated that contents related to emotional needs (need for understanding and care) are part of the repertoire of beliefs concerning the HIV/ AIDS patient and are positively valued, regardless of history of accidental exposure to blood.

The results for the patient category indicate the importance of the patient's role in the health care workers' work and the perception of difficulties at the biological, psychological, and social levels experienced by the HIV/AIDS patient. In this category, two items showed statistically significant differences between the accidentally exposed and non-exposed health care workers subgroups: the item related to the importance of patients' perceiving their improvement and the item related to patients' remorse over having been exposed to HIV. In the first case, although significant differences were 
Final list of statements selected by content analysis.

\begin{tabular}{|c|c|c|}
\hline Category & Item & Statement \\
\hline \multirow[t]{8}{*}{ Work } & 1.2 & To work with AIDS it is necessary to understand the patient \\
\hline & 1.3 & To work with AIDS it is necessary to treat the patient with care \\
\hline & 1.8 & Work at the SUTID differs from work in other departments \\
\hline & 1.11 & It is difficult to work calmly in the context of AIDS care \\
\hline & 1.12 & Working at the SUTID is a challenge \\
\hline & 2.2 & The patient is the health care worker's main source of motivation \\
\hline & 2.3 & The patient is considered part of the HCW's family \\
\hline & 2.1 & The patient with AIDS is in a state of revolt \\
\hline \multirow[t]{7}{*}{ Patient } & 2.10 & The patient is skeptical regarding his/her chances at the beginning of treatment \\
\hline & 2.15 & The patient with AIDS has biological, psychological, and social problems \\
\hline & 2.6 & It is important for the patient to perceive his/her improvement \\
\hline & 2.7 & Some patients feel remorse for having been exposed to HIV \\
\hline & 3.1 & The risk of $\mathrm{AEB}$ makes the $\mathrm{HCW}$ apprehensive throughout the work period \\
\hline & 3.2 & Accidental exposure causes complications for the HCW \\
\hline & 3.3 & AEB causes despair in the $\mathrm{HCW}$ \\
\hline \multirow[t]{5}{*}{ Accident } & 3.10 & AEB causes revolt in the $\mathrm{HCW}$ \\
\hline & 3.12 & The risk of AEB poses an obstacle for the HCW's work \\
\hline & 3.4 & AEB can be caused by haste \\
\hline & 3.14 & Accidents occur in emergency situations when procedures have to be performed quickly \\
\hline & 3.15 & Accidents occur due to excessive self-confidence on the part of the HCW \\
\hline
\end{tabular}

$\mathrm{HCW}=$ health care workers; SUTID = Special Unit for Treatment of Infectious Diseases;

$\mathrm{AEB}=$ accidental exposure to blood.

Table 2

Results of analysis of instrument for evaluation of needs and motivation, in health care workers with and without a history of accidental exposure to blood.

\begin{tabular}{|c|c|c|c|c|c|c|c|c|c|c|}
\hline \multirow[t]{3}{*}{ Satisfaction level } & \multicolumn{10}{|c|}{$\begin{array}{c}\text { Need level and satisfaction } \\
\text { Needs level }\end{array}$} \\
\hline & \multicolumn{2}{|c|}{ Survival } & \multicolumn{2}{|c|}{ Safety } & \multicolumn{2}{|c|}{ Needs level } & \multicolumn{2}{|c|}{ Self-esteem } & \multicolumn{2}{|c|}{ Self-fulfillment } \\
\hline & $\mathrm{N}$ & $A$ & $\mathrm{~N}$ & A & $\mathrm{N}$ & A & $\mathrm{N}$ & A & $\mathrm{N}$ & A \\
\hline Satisfied & - & - & $64 \%$ & $54 \%$ & $36 \%$ & $10 \%$ & $4 \%$ & $4 \%$ & $64 \%$ & $40 \%$ \\
\hline Unsatisfied & $54 \%$ & $72 \%$ & - & - & - & $4 \%$ & $41 \%$ & $7 \%$ & - & - \\
\hline Not significant & $46 \%$ & $28 \%$ & $36 \%$ & $46 \%$ & $64 \%$ & $86 \%$ & $55 \%$ & $89 \%$ & $36 \%$ & $60 \%$ \\
\hline
\end{tabular}

Not significant $=$ not statistically significant $(\alpha>0.1) ; \mathrm{N}=$ health care workers without a history of accidental exposed to blood; $A$ = health care workers with a history of accidental to blood.

detected, conjugation of the responses pointed in the same direction, i.e., patients perceive their improvement and this is viewed positively (item 2.7, Table 3). As for HIV/AIDS patients' remorse over having been exposed to the virus, the results indicate that only professionals who were never accidentally exposed to HIV believe in and positively value such an attitude. For professionals who have been accidentally exposed, the results do not indicate a prevalent quadrant.

Analysis of the accident category did not show any significant difference between the two sub-samples for the items evaluated.

Analysis of the "b"/ "e" conjugation for the whole sample showed the presence of strong 
Summary results of quadrant analysis for " $b " x$ " $e$ " conjugation of the categories work, patient, and accident.

\begin{tabular}{|c|c|c|c|c|c|c|}
\hline Category & Item & Group & $p$ & $\mathrm{Zp}$ & QDT & "b" x "e" conjugation \\
\hline \multirow[t]{5}{*}{ Work } & 1.2 & Total & 0.85 & 11.59 & C & $\begin{array}{l}\text { Very strong, positively valued belief that understanding the patient } \\
\text { is necessary for working with AIDS }\end{array}$ \\
\hline & 1.3 & Total & 0.85 & 11.59 & C & $\begin{array}{l}\text { Very strong, positively valued belief that treating the patient with care } \\
\text { is necessary for working with AIDS }\end{array}$ \\
\hline & 1.8 & Total & 0.52 & 0.57 & C & Not significant \\
\hline & 1.11 & Total & 0.28 & -6.92 & $E$ & Not significant \\
\hline & 1.12 & Total & 0.44 & -1.71 & C & Not significant \\
\hline \multirow[t]{9}{*}{ Patient } & 2.2 & Total & 0.68 & 5.46 & C & $\begin{array}{l}\text { Very strong, positively valued belief that the patient is the main source } \\
\text { of motivation for the HCW }\end{array}$ \\
\hline & 2.3 & Total & 0.30 & -6.17 & $E$ & Not significant \\
\hline & 2.1 & Total & 0.44 & -1.71 & $\mathrm{H}$ & Not significant \\
\hline & 2.10 & Total & 0.52 & 0.57 & 1 & Not significant \\
\hline & 2.15 & Total & 0.72 & 0.93 & 1 & $\begin{array}{l}\text { Very strong, positively valued belief that the AIDS patient has biological, } \\
\text { psychological, and social problems }\end{array}$ \\
\hline & 2.6 & A & 0.96 & 24.86 & C & $\begin{array}{l}\text { Very strong, positively valued belief that the AIDS patient perceives } \\
\text { his/her improvement }\end{array}$ \\
\hline & 2.6 & $\mathrm{~N}$ & 0.86 & 9.74 & C & $\begin{array}{l}\text { Very strong, positively valued belief that the AIDS patient perceives } \\
\text { his/her improvement }\end{array}$ \\
\hline & 2.7 & A & 0.53 & 0.63 & C & Not significant \\
\hline & 2.7 & $\mathrm{~N}$ & 0.60 & 1.92 & C & $\begin{array}{l}\text { Very strong, positively valued belief that the AIDS patient feels remorse } \\
\text { for having been exposed HIV }\end{array}$ \\
\hline \multirow[t]{8}{*}{ Accident } & 3.1 & Total & 0.24 & -8.66 & $E$ & Not significant \\
\hline & 3.2 & Total & 0.60 & 2.86 & 1 & $\begin{array}{l}\text { Very strong, negatively valued belief that } A E B \text { causes complications } \\
\text { for the personal life of the HCW }\end{array}$ \\
\hline & 3.3 & Total & 0.54 & 1.14 & 1 & Not significant \\
\hline & 3.10 & Total & 0.40 & -2.86 & 1 & Not significant \\
\hline & 3.12 & Total & 0.40 & -6.15 & $E$ & Not significant \\
\hline & 3.4 & Total & 0.64 & 4.12 & 1 & Very strong, negatively valued belief that $A E B$ can be caused by haste \\
\hline & 3.14 & Total & 0.40 & -2.86 & 1 & Not significant \\
\hline & 3.15 & Total & 0.26 & -7.74 & $\mathrm{E}$ & Not significant \\
\hline
\end{tabular}

$\mathrm{p}=$ ratio; $\mathrm{Zp}=$ prevalent quadrant; $\mathrm{QDT}=$ quadrant; $\mathrm{N}=$ health care workers without a history of accidental exposure to blood;

$A=$ health care workers with a history of accidental exposure to blood.

beliefs for two items, which were negatively valued by the subjects: the fact that accidental exposure to blood results in complications in the lives of health care workers and the possibility that occupational exposure to HIV may have been caused by haste.

\section{Discussion}

The results indicate that health care workers' professional practice extrapolates intrinsic technical aspects, requiring consideration of the psychosocial needs of HIV/AIDS patients during daily work. A tendency of professional activity based on the search for self-fulfillment can be observed. Since the clinical and psy- chosocial aspects of AIDS are quite complex, health care workers involvement with the work and patients becomes a privileged and essential instrument for a favorable treatment prognosis.

With respect to the work itself, beliefs and values identified among health care workers demonstrate awareness of patients' emotional needs. Meanwhile, patient care represents a component of the professional role which in turn shifts the recognition of technical and scientific competence to another level of meaning that is necessary but not sufficient to treat AIDS.

Strawn 22 reports that people react individually to life-threatening diseases, especially AIDS. Therefore, reactions are related to the meaning each person ascribes to both the dis- 
ease and its extent and physical and mental consequences. Stigmatized diseases entail the fear not only of death, but also of discrimination and possible interference with social and affective relationships.

The affective elements in the relationship between health care workers and HIV/AIDS patients require reflection on the possibility of maintaining a safe distance between technical knowledge and emotional involvement. Health care workers appear to distance themselves from the reality of daily difficulties and to act by idealizing their work, viewing patients as deserving of care and understanding, even though they need to distance themselves from judgments regarding HIV infection routes and lifestyles.

Such idealization also influences health care workers' perceived capacity to exercise their functions, even though they may not feel completely secure or exempt from infection by accidental exposure to blood. A distancing process from the concrete risk of accidental exposure to blood and HIV infection is observed here, which enables Health care workers to continue their search for self-fulfillment.

This idealization suggests a feeling of omnipotence which Figueiredo \& Turato 6 see as a determinant in the choice of the profession itself, making health care workers feel consciously or unconsciously more empowered within the context of human vulnerability to disease and death.

We observed a predominance of beliefs concerning the affiliation process situating patients in first place in the lives of health care workers. Since patients represent the main motivation for the performance of health care workers' professional functions, treatment evolution and response also depend on the success of those providing patient care, thus ultimately leading to a "dilution" of the control over their performance itself. Professional self-esteem also depends on the patient's condition, mainly because health care workers assume the obligation to maintain patients under treatment and to provide them with care in order to guarantee their quality of life based on information and support.

A significant difference in health care workers' self-esteem was observed using accidental exposure to blood as a parameter. Health care workers without a history of accidental exposure to blood were unsatisfied with their desire to be properly recognized for their work. We can assume that health care workers who have been accidentally exposed to blood draw somewhat closer to the universe of the patient's rep- resentation of health care workers' professional role. The importance of this role for maintaining the connection with life thus becomes clearer, especially during contact between the health care workers and the patient.

Due to changes in AIDS treatment, health care workers have begun to act within a different reality. The introduction of highly active antiretroviral therapy (HAART) has turned AIDS into a chronic disease, leading to better quality of life and thus longer survival for patients. This process poses an ongoing challenge for health care workers, who must constantly strive to review their motivations and difficulties in order to continue caring for patients 23 .

Another level of representation refers to the impact of AIDS on patients and their resulting feeling of revolt, besides the diagnosis/prognosis of infection. Health care workers working with AIDS may not significantly express a certain direction, indicating the real or internally felt difficulties in judging the reactions of the patients who show a heavily negative emotional content such as a feeling of revolt.

Health care workers see patients with HIV/ AIDS as "difficult", based on their direct daily contact and the difficulties arising in this coping process, leading to obstacles that impact these daily relationships. Health care workers recognize that the "psychological component" represents a special dimension of care, and the term "difficult" thus appears to be associated with aggressiveness, demands, needs, revolt, anxiety, and depression 24 .

Another belief among health care workers relates to the fact that some patients feel remorse over their HIV exposure; however, the present study showed a difference between health care workers with and without a history of accidental exposure to blood. Health care workers without a history of accidental exposure to blood positively value such feelings of remorse in patients, based on the belief that patients can redeem themselves, allowing a process of acceptance and affiliation. Meanwhile, responses from those with a history of accidental exposure to blood suggest a difficulty in rationally evaluating the possibility of patients' recognition of the options and choices they have made earlier in life.

This difference indicates that the responsibility for possible HIV infection through accidental exposure to blood appears to be related to the so-called passive forms of infection (by blood transfusion or mother-to-child transmission). According to Figueiredo \& Turato 6 , in such cases health care workers show sorrow and identify with patients, while almost never 
questioning the individual's shared responsibility. Therefore, health care workers succeed in distancing themselves from their own responsibility for avoiding accidental exposure to blood through the proper use of universal precautions and personal protective equipment.

However, typical reactions at the time of accidental exposure to blood, ranging from fear and emotional problems to despair, as reported in different studies, appear to trigger the need to examine health care workers' beliefs and myths about patients. Health care workers' capacity to distance themselves from real suffering is jeopardized, and they therefore identify with patients and consequently with the whole range of prejudices and taboos surrounding patients' lives. Health care workers become the target of AIDS-related stigmata, thus forcing them to face their fears in caring for these patients $8,25,26$.

Souza 27 has observed not only a concern on the part of health care workers about accidental exposure to blood but also a return to their own concepts about patients and their lifestyles, with a predominant emergence of prejudices regarding risk behaviors. The mode of infection, views concerning risk behaviors, and personal judgment frequently permeate the relationships between health care workers and HIV/AIDS patients in their daily contact 28 . health care workers are also subject to the same discrimination, even within their own social group.

Tribonnière et al. 26 observed feelings of anxiety, rage, anger, insomnia, and depression among health care workers following accidental exposure to blood. The ability to accept negative feelings towards work and patients appears to be facilitated by the accidental exposure to blood, accompanied by the subjective presence of prejudices and judgment during Health care workers' contact with HIV/AIDS patients $24,27,28$.

AIDS-related fear is also akin to other fears such as abandonment by family and friends, rejection by society, and contact with life and death. Post-exposure prophylactic measures are also uncomfortable and expose health care workers to circumstances similar to those experienced by AIDS patients, e.g., the large pill burden, sometimes highly inconvenient side effects, the need to use condoms in all sexual relations, and the necessary care to avoid pregnancy during the observation period. Accidental exposure to blood renders health care workers as vulnerable as their patients.

According to all evidence, the possibility of HIV infection through accidental exposure to blood makes health care workers aware of more immediate issues which had previously been located at another level of representation. This is when health care workers realize that basic needs associated with reality such as safety at work and one's own health invariably lie on shaky ground. Fear of discrimination and social rejection also begins to influence the lives and work of these health care workers.

Therefore, the two poles of representation and conduct by health care workers caring for HIV/AIDS patients are defined between the loss of contact with real immediate risks and over-valuing of the possibility of reducing patients' suffering, on which is based a major portion of the expectations for personal and professional fulfillment.

A third level of revelation regarding technical aspects that impact work is the belief that haste may be a cause of accidental exposure to blood. However, this contingency appears to be associated with other difficulties in the work setting, such as insufficient staff, increasing neglect of personal protective equipment over time, inadequate procedures for disposing of sharps and other materials, haste during procedures, and teamwork difficulties.

Some studies 8,26 have emphasized that many health care workers with a history of accidental exposure to blood were able to modify habits, especially those associated with the use of universal precautions and personal protective equipment.

Professionals who succeed in consistently working out the situation following accidental exposure to blood and reconsidering their lives by viewing the past events in a normal light show important cognitive responses, leading to transformation of their work in terms of occupational safety. Souza 27 observed that responses are not always determined exclusively by the stressful situation, but also depend on prior experience and personal beliefs.

In conclusion, the complexity of HIV/AIDS patient care results in significant emotional stress, indicating the importance of actions that offer favorable working conditions including help and psychological support for health care workers in order to establish a less threatening and more genuine relationship with HIV/AIDS patients. 


\section{Resumo}

O objetivo deste estudo foi analisar determinantes afetivos e cognitivos que influenciam o trabalho de profissionais que cuidam de pessoas vivendo com o HIVI AIDS, frente ao risco ou experiência de exposição acidental a material biológico potencialmente contaminado (MBPC). Utilizou-se o referencial teórico metodológico de Fishbein-Ajzen e a teoria de Maslow, que propõe a hierarquia das necessidades humanas. Cinqüenta profissionais de saúde foram avaliados por meio de escalas de atitudes, e de um instrumento de avaliação de necessidades e motivações. Verificou-se a diferença entre as respostas de profissionais que nunca sofreram acidente e aqueles que já passaram pela experiência de acidente ocupacional. Os resultados indicam que os profissionais exercem suas atividades motivados pela necessidade de auto-realização e valorizam sua performance quando podem atender as necessidades emocionais dos pacientes. Para os profissionais que não se acidentaram predominam crenças de que os pacientes se arrependem da exposição ao HIV. O episódio de acidente acarreta dificuldades à vida pessoal e profissional do trabalhador acidentado. Aspectos técnicos também aparecem associados à possibilidade de ocorrência de acidentes.

Assistência à Saúde; Acidentes de Trabalho; Síndrome de Imunodeficiência Adquirida

\section{Contributors}

M. R. R. Rissi participated in the development of the research and drafting of the article. A. A. Machado and M. A. C. Figueiredo contributed with the choice and utilization of the research methodology and collaborated in the analysis of the results and drafting of the discussion.

\section{Acknowledgments}

We thank the health care staff from the Special Unit for Treatment of Infectious Diseases and all the individuals who participated directly or indirectly in the present study.

\section{References}

1. Tokars JI, Marcus R, Culver DH, Schable CA, McKibben PS, Bandea CI, et al. Surveillance of HIV infection and zidovudine use among health care workers after occupational exposure to HIV-infected blood. Ann Intern Med; 1993; 118:913-9.

2. Centers for Disease Control and Prevention. Update: provisional public health service recommendations for chemoprophylaxis after occupational exposure to HIV. MMWR Morb Mortal Wkly Rep 1996; 45:468-80.

3. Puro V, Ippolito G. Brief report: effect of antiretroviral agents on T-lymphocyte subset counts in healthy HIV-negative individuals. The Italian registry on anti-retroviral postexposure prophylaxis. J Acquir Immune Defic Syndr 2000; 24:440-3.

4. Figueiredo RM, Garcia MT, Resende MR, Papaiordanou PMO. Adherence of professionals to follow-up treatment after exposure to contaminated material in a Brazilian university hospital. Infection Control Hosp. Epidemiol 2000; 21:109-12.

5. Machado AA, Ujkawa LT, Castro G, Abduch R, Matos US. Occupational exposure to potentially contaminated material among health care workers at the university hospital. In: Anais do Congresso de Controle de Infecções e Epidemiologia Hospitalar, III Congresso Pan-Americano, VII Congresso Brasileiro, I Congresso de Odontologia de Minas Gerais; 2000 Nov 10-14; Belo Horizonte, Brasil. Belo Horizonte: Associação Brasileira de Controle de Infecção Hospitalar; 2000. p. 109.

6. Figueiredo RM, Turato ER. A enfermagem diante do paciente com AIDS e a morte. J Bras Psiquiatr 1995; 44:641-7.

7. Weiss SH. Risks and issues for the health care worker in the human immunodeficiency virus era. Med Clin North Am 1997; 81:555-75.

8. Souza A. Risco biológico e biossegurança no cotidiano de enfermeiros e auxiliares de enfermagem [Dissertação de Mestrado]. Ribeirão Preto: Escola de Enfermagem de Ribeirão Preto, Universidade de São Paulo; 2000.

9. Canini SR, Gir E, Hayashida M, Machado AA. Acidentes perfuro-cortantes entre trabalhadores de enfermagem de um hospital universitário do interior paulista. Rev Lat Am Enfermagem 2002; 10:172-8.

10. Carson V, Soeken KL, Shanty J, Terry L. Hope and spiritual well-being: essentials for living with AIDS. Perspect Psychiatr Care 1990; 26:28-34.

11. Cardo DM, Culver DH, Ciesielsky CA, Srivastava PU, Marcus R, Abiteboul D, et al. A case-control study of HIV seroconversion in health care workers after percutaneous exposure. N Engl J Med 1997; 337:1485-90.

12. Rissi MRR. Profissionais de Saúde e AIDS: um estudo diferencial frente a ocorrência de acidente ocupacional com material biológico potencialmente contaminado [Dissertação de Mestrado]. Ribeirão Preto Faculdade de Filosofia, Ciências e Letras de Ribeirão Preto, Universidade de São Paulo; 2001.

13. Flaskerud JH. Psychosocial aspects of AIDS. J Psych Nurs 1987; 25:9-16.

14. Miller D. HIV/AIDS health worker stress and 
burnout: introduction and overview. AIDS Care 1996; 8:133-5.

15. Ajzen I, Fishbein M. Attitudinal and normative variables and predictors of behavior. J Pers Soc Psychol 1973; 1:41-57.

16. Osgood CE, Suci GJ, Tannenbaum PH. The measurement of meaning. Urbana: University of Illinois Press; 1957.

17. Maslow A. Toward a psychology of being. 2nd Ed New York: Van Nostrand; 1968.

18. Maslow A. Motivation and personality. 2nd Ed New York: Harper \& How; 1970.

19. Rissi MRR, Machado AA, Figueiredo MAC. Fear of occupational accidents and its effect on the performance of health workers caring for patients with acquired immunodeficiency syndrome (AIDS). In: Proceedings of the 13th World Aids Conference; 2000 Jul 9-14; Durban, South Africa. Bologna: Monduzzi Editore; 2000. p. 147-51.

20. Figueiredo MAC. Escalas afetivo-cognitivas de atitude. Construção, validação e interpretação dos resultados. In: Romanelli G, Biasoli-Alves M, organizadores. Diálogos metodológicos sobre prática de pesquisa. Ribeirão Preto: Legis Summa; 1998. p. 51-70.

21. Fioroni LN. Modos de enfrentamento da AIDS e condições de vida: estudo baseado em fatores de personalidade e hierarquia de necessidades [Dissertação de Mestrado]. Ribeirão Preto: Faculdade de Medicina de Ribeirão Preto, Universidade de São Paulo; 2000.
22. Strawn JM. As conseqüências psicossociais da AIDS. In: Durhan JD, Cohein FL, organizadores. A enfermagem e o aidético. São Paulo: Manole; 1989. p. 126-49.

23. Teixeira PR, Paiva V, Shimma E. Tá difícil engolir? Experiências de adesão ao tratamento anti-retroviral em São Paulo. São Paulo: Núcleo de Estudos em Prevenção de AIDS, Universidade de São Paulo; 2000.

24. Bennett L. AIDS health care: staff stress, loss and bereavement. In: Sherr L, editor. Grief and AIDS. New York: John Wiley \& Sons; 1995. p. 87-102.

25. Niven CA, Knussen C. Measuring the stress associated with caring clients with HIV/AIDS. AIDS Care 1999; 11:171-80.

26. De La Tribonnière $X$, Dufresne MD, Alfandari S, Fontier C, Sobazek A, Valette M, et al. Tolerance, compliance and psychological consequences of post-exposure prophylaxis in health-care workers. Int J STD AIDS 1998; 9:591-4.

27. Souza M. Acidentes ocupacionais e situações de risco para equipe de enfermagem: um estudo em cinco hospitais do Município de São Paulo [Dissertação de Mestrado]. São Paulo: Escola Paulista de Medicina, Universidade Federal de São Paulo; 1999.

28. Meneghin P. Entre o medo da contaminação pelo HIV e as representações simbólicas da Aids: o espectro do desespero contemporâneo. Rev Esc Enferm USP 1996; 30:399-415.

Submitted on $16 / \mathrm{Jul} / 2003$

Final version resubmitted on $17 / \mathrm{Dec} / 2003$

Approved on 05/Feb/2004 